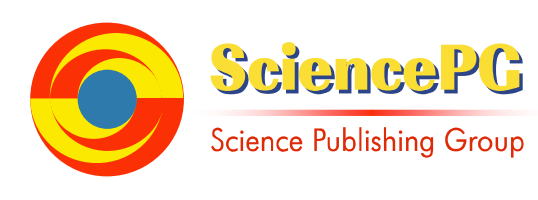

\title{
Evaluating Kurdish EFL University Students' Comprehension of Commercial Advertisements with Reference to Leech's Types of Meaning
}

\author{
Barham Sattar Abdulrahman \\ Department of English, School of Basic Education, Faculty of Physical and Basic Education, University of Sulaimani, Sulaimani, Kurdistan, \\ Iraq
}

\section{Email address: \\ barham_star@yahoo.com}

\section{To cite this article:}

Barham Sattar Abdulrahman. Evaluating Kurdish EFL University Students' Comprehension of Commercial Advertisements with Reference to Leech's Types of Meaning. International Journal of Language and Linguistics. Vol. 3, No. 6, 2015, pp. 455-465.

doi: $10.11648 /$ j.ij11.20150306.30

\begin{abstract}
The current study highlights different types of meaning, conceptual and associative meaning in particular, and their role(s) in some selected English and Kurdish commercial advertisements. It aims at detecting and evaluating the capability of Kurdish EFL university students in comprehending (or decoding) these advertisements. The material to be investigated is the texts that accompany the pictorial element(s) of some English and Kurdish ads. The ads are carefully selected to represent different fields: lottery, food, technological devices, telecommunication system, healthcare, etc. The study assumes that advertising is determined by two essential features, namely universal and national; both have serious impact on the persuasive character of the ads. Moreover, it is hypothesized that the language used to support the pictorial elements of an ad, unless well-selected to affect and promote people's desire, might have negative consequences on marketing it. The study also hypothesizes that the students comprehend Kurdish ads easily comparing with the English ones. To investigate the hypotheses five samples of ads in each language are selected and analyzed according to well-defined criteria based on Leech's types of meaning; and a test is designed to evaluate the students' comprehension in which the students are asked to write their own understanding on the texts found in the ads. The study concludes that in each text different types of meaning are available and the type that supports conveying the hidden message is the associative meaning rather than conceptual one. Moreover, the study concludes that because of their lack of most aspects of English culture, the level of students' comprehension of Kurdish ads is higher than the English ones.
\end{abstract}

Keywords: Advertising, Meaning, Comprehension

\section{Introduction}

We live in a world that is completely determined by the power of advertising. Advertisements (henceforth ads) motivate people, promote their desires, and orient their choices. TV channels, newspapers and magazines, Internet, and other social media are the effective tools manipulated by manufactures, companies, and different media institutions to direct people (customers and/or consumers) desire toward realizing their objectives.

Williamson (1983: 11-14) states that no one can escape from ads; even if a person does not read newspapers, watch $\mathrm{TV}$, access to the net- webs and social media, etc., s/he cannot escape from the images posted in surroundings (i.e., street advertising or outdoor ads).

The language used in advertising is an influential tool at the hands of ad designers who work on emotionally changing people's perspective about a product; they make people positively react toward a certain service or product. The linguistic items used in any text are highly selected in order to attract customer's attention so as to buy a product. In this sense, the ads can be considered as a communicative tool; a tool that connects customers with the product especially at the emotional level (see Bowdery, 2008).

Pedagogically speaking and building on the researcher's teaching experience, almost all of the Kurdish EFL university students usually face problems in comprehending the cultural implications of language in general and understanding the intended message behind designing English ads, in particular. 
The reason behind this could be attributed to the fact that Kurdish EFL university students are not fully aware of the English culture and lack of having knowledge about designing ads and their effects on people.

\section{Meaning and Its Types}

The concept of "meaning" is controversial; there is no agreement on what meaning is (Lyons, 1981: 136). What is the meaning of 'meaning' is another complicated issue with no satisfactory solution (Ogden and Richards, 1923: 185207).

Lyons (1981: 36) believes that linguists do accept the concept of 'meaning' in the theory of semantics as the "ideas or concepts, which can be transferred from the mind of the speaker to the mind of the hearer by embodying them, as it were, in the forms of one language or another." Furthermore, Lyons (1977: 1) claims that a person cannot understand and/or explicate the linguistic meaning unless s/he regards to other types of non-linguistic meaning. (see Palmer, 1981: 15; Widdowson, 1996: 27; Bussmann, 1996: 1048; Löbner, 2002, 3; Saeed, 2003: 3; O’Grady, 2005: 201; Yule, 2006: 100; Kearns, 2011: 1).

Leech (1981: 1-8) gives a detailed description of the concept of 'meaning' and 'meaning of meaning' and a chronological order (starting from 1923) about the ideas declared by scholars in this regard. Besides he states that meaning necessarily must be studied in the field of language as a 'linguistic phenomenon'; it is not something outside the border of language, i.e., investigating what it is to know a language semantically. On the top of everything else, he attempts to break down 'meaning' into seven different types, two of which are the main concern of the current study: conceptual meaning and associative meaning.

\subsection{Conceptual Meaning (or Sense)}

Leech (1981: 9); Akmajian et al. (1995: 218) among many others believe that cognitive meaning is the central factor of daily conversation. People are able to communicate and understand what they receive when they refer to the cognitive meaning. So, conceptual meaning has its own importance in most of linguistic communication since each single expression has meaning and the meaning is the actual object it indicates.

According to Leech (1981: 9-11) conceptual meaning is based on two structural principles: contractiveness and structure. When one takes these principles into account while talking about conceptual meaning, one can say that this type of meaning is sophisticated. The reason behind that is attributed to the fact that three linguistic disciplines (phonology, syntax, and semantics) should be taken into consideration. So, in analyzing any sentence, one may need drawing phonological, syntactic and semantic representation and "the stages by which one level of representation can be derived from another."

Other scholars also contributed to defining 'conceptual meaning'. For instance, Crystal (2008: 84) states that it covers "those aspects of meaning which related directly with denotations of lexical items and the propositional content of sentences." Moreover, Crystal (1992: 80) refers to conceptual meaning as the dictionary meaning-dictionary listed words. So, a word like 'car' includes some essential meaning such as "vehicle with four wheels, engine for carrying the passengers, engine for transportation, etc." These could be a part of the conceptual meaning of 'car' (cf. Hurford at al., 2007: 90). Other linguistic terms such "cognitive meaning, dictionary meaning, literal meaning, referential meaning and denotative meaning" can be used interchangeably with conceptual meaning.

\subsection{Associative Meaning}

Associative meaning is wider and more complex than conceptual meaning since it has psychological connections related to the association of one's ideas, life experience, etc. In this sense, associative meaning is attached to any word in order to be used is in daily communication; whereas meaning itself is not part of the word core sense, but of a number of psychologically connected items which come to mind, i.e., associations (Finch, 2000: 15; Crystal, 2008: 41). So, building on different life style that people have, one may claim that associative meaning is different from one person to another - taking the psychological (and sociological) dimension of someone's life into account.

Many linguists do believe that any word has a meaning which cannot be treated as a part of its cognitive meaning. They give a number of examples to support their claim. For example, Yule (2006: 100) states that a word like 'needle' can be associated with pain, blood, thread, hard to find, drugs, etc. and these associations, differ from one person to another. Furthermore, poets, novelists, advertisers and lovers are more interested in using words that involve meaning association while semanticists are more concerned with analyzing conceptual meaning. On the other hand, Kuiper and Allan (1996: 176) claim that abstract nouns and those which indicate internal states are ambiguous; a word like 'bravery' is harder to be defined or introduced comparing with a concrete noun since it denotes social properties. This is why Leech (1981) categorizes associative meaning into further five types of meaning: Reflected, Collocative, Connotative, Affective, and Social. The following table and comments illustrate Leech's seven types of meaning clearly.

Table 1. Leech's Seven Types of Meaning (1981: 23).

\begin{tabular}{|c|c|c|}
\hline $\begin{array}{l}\text { 1. Conceptual } \\
\text { Meaning (or } \\
\text { Sense) }\end{array}$ & \multicolumn{2}{|c|}{$\begin{array}{l}\text { Meaning that is communicated by the literal use of } \\
\text { language (logical, cognitive, or denotative content). }\end{array}$} \\
\hline \multirow{4}{*}{$\begin{array}{l}\text { 2. Associative } \\
\text { Meaning }\end{array}$} & $\begin{array}{l}\text { 2.1 Connotative } \\
\text { Meaning }\end{array}$ & $\begin{array}{l}\text { What emotional associations are } \\
\text { communicated by virtue of what } \\
\text { language refers to. }\end{array}$ \\
\hline & 2.2 Social & What is communicated of the social, \\
\hline & Meaning & circumstances of language use. \\
\hline & $\begin{array}{l}2.3 \text { Affective } \\
\text { Meaning }\end{array}$ & $\begin{array}{l}\text { What is communicated of the } \\
\text { feelings and attitudes of the } \\
\text { speaker/writer. }\end{array}$ \\
\hline
\end{tabular}




\begin{tabular}{ll}
\hline $\begin{array}{l}\text { 2.4 Reflected } \\
\text { Meaning }\end{array}$ & $\begin{array}{l}\text { What is communicated through } \\
\text { association with another sense of the } \\
\text { same expression. }\end{array}$ \\
$\begin{array}{l}\text { 2.5 Collocative } \\
\text { Meaning }\end{array}$ & $\begin{array}{l}\text { What communicated through } \\
\text { association with words which tend } \\
\text { to occur in the environment of } \\
\text { another word. }\end{array}$ \\
2.6 Thematic & $\begin{array}{l}\text { What is communicated by the way } \\
\text { in which the message is organized in } \\
\text { terms of order and emphasis. }\end{array}$ \\
\hline
\end{tabular}

\section{Ads in Mass Media}

An advertisement in a newspaper, radio, TV, Internet and any other media is an announcement of something (usually a company product) or call for joining an important event (Wehmeier, 2000: 241). Most of the companies spend money, time, and effort to name their product(s), or to design an ad. They work hardly and carefully to select the most effective and meaningful advertising language in order to attract public attention. Kreidler (1998: 2-3) mentions three disciplines which have a close relationship with semantics: psychology, philosophy, and linguistics. Although these principles are different in terms of interest and approach, they are related to each other and shape the reality of something, events, etc. To be more specific, psychologists deal with the questions such as "How someone learns? How s/he saves/loses information?" In other words, how one's mind works while seeking meaning. Philosophers concentrate on questions like "How one knows? How to relate what one knows with other possible facts? Does one express the same meaning in different words, how? etc. Moreover, linguists attempt to realize how language (as a system) works and how people possess and share their common knowledge and how they invest all of this to identify the meaningful elements of language(s).

\section{Students' Comprehension of Ads}

Comprehension, the main concern of the study, refers to understanding what humans hear and/or read. Moreover, it is about how language is processed in human's mind and how different types of memory are used to understand and interpret language. So, in a very simple language, comprehension is turning linguistic items into ideas. Garman (1990: 305) mentions some other terms such as recognition, interpretation, perception, and understanding which can be associated with the notion of comprehension. Many, if not most, of the scholars do use comprehension rather than the other terms. The reason behind this, as highlighted by Garman (1990), could be attributed to the fact that comprehension is used as a cover for interpretation and understanding.

Not surprisingly, the mental process of comprehension starts from the comprehension of sounds, to the comprehension of words, sentences and texts (Tanenhaus, 1998: 7-17; Aitchison, 2008: 206-26; Goldstein, 2008: 36081 ); building on this, one can claim that comprehension is automatic and fast. At the same time, the psychological processes of comprehending a linguistic chunk are complex.

Pedagogically speaking, comprehension refers to a student's ability to grasp the meaning of a particular text (literary, scientific, journalistic, etc.). The students' educational, cultural, and social background knowledge influences their comprehension. So, a student's recognition, interpretation, perception, and understanding should be different from another student of a different social background. Predictably then, following one of the psycholinguistics' goal, a number of Kurdish senior university students are asked to write their own comprehension about some selected English and Kurdish commercial ads. The results are expected to have similarities and differences since they belong to the same society, nation, and religion with different social status and family background.

\section{Data Collection}

In order to obtain data for the study and investigate the senior students' comprehension of some English and Kurdish commercial ads, a test has been designed to elicit and evaluate the Kurdish EFL university students' ability to analyze and understand the selected commercial ads with reference to Leech's types of meaning (e.g., conceptual, associative). The students are supposed to carefully read the texts given in the ads and write their own understanding. Furthermore, 20 students (10 males and 10 females) from Department of English, School of Basic Education, Faculty of Physical and Basic Education, University of Sulaimani are selected as a sample. They have been given a detailed description of Leech's types of meaning; during their academic course, they had a threeday session about meaning, especially Leech's categorization of meaning. The students have been given brief instructions as how to respond to the test. The test consists of two parts: English ads and Kurdish ads. Each part consists of five ads of different fields of commerce (e.g., telecommunication, food, cigarette, lottery, technology, businesses, private sector, etc.). In order to analyze the study data, a set of criteria is set which includes different kinds of meaning.

\section{Data Analysis and Results}

As it has been highlighted earlier, in order to describe the conceptual meaning of ad, one might need to draw phonological, syntactic and semantic representations of it; the current study focuses on the semantic one only. The study data is analyzed both descriptively and statistically in order to reveal Leech's different types of meaning in the ads and the students' comprehension of them as well. Below are some selected English and Kurdish ads and the students' comprehension have been analyzed: 


\subsection{Analyzing Selected English Ads}

\section{IT COULD BE YOU.}

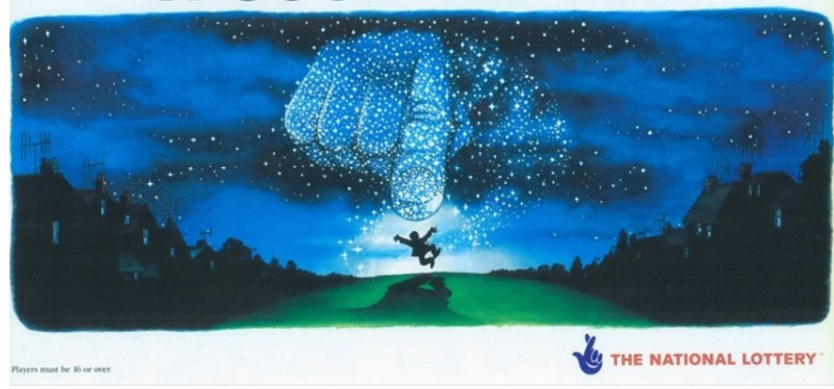

Ad. 1. It could be you!

This expression (with an exclamation mark) is used in advertising for the British National Lottery. The word order, of course, affects people who see or hear it- amazing idea! The aim of designing this ad and choosing the simple words is to attract people attention and collect more and more money. Since it tells audience that any person could be the winner, people may try their best to try it even once.

The language of this ad (It could be you!) does not provide the audience with any information. However, building on the audience life experience, one might think of a lot of good things. Psychologically speaking, it evokes one's ego and self-confidence. Philosophically speaking, it encourages people to keep on looking for truth. With regard to the conceptual meaning of each linguistic item found in the ad (Pronouns 'it' and 'you', the modal 'could', and the exclamation mark), one conceptualizes of it as an invitation to win or realize something exceptional. With respect to associative meaning, one can state that 'the winner' or 'you' are the connotative meaning of 'it'. 'You' is associated with meaning; it may be different from one person to another. It may stand for 'rich person', 'winner', 'lots of money', 'better life', 'big house and best car', 'charity', 'bank', etc. This, however, may vary according to different cultures. With reference to social meaning, it can be said that the pronoun "you" has a historical root, for example: 'you' is the recent use for the $2^{\text {nd }}$ person, 'thee' is an 'archaic regional', and 'thou' can be considered as 'old use or dialect' (see Crystal and Davy, 1969: 64-77). Finally, the message of the ad is that everyone could be the winner and become the owner of the lottery; this may change people's reaction and perspective towards the lottery. So, the language used in the ad attempts to operate on the audience emotional and psychological response; that is why a very simple and casual language is used (i.e., affective and social meaning).

Statistically speaking, nine students which equal $45 \%$ do believe that they do not like this type of ad since no one can get the lottery. This could be connected with their real life experience that winning this lottery is next to impossible. It seems that this number of students have a positive feeling (or probably previous experience) about the lottery in general. For $35 \%$ of the students, this ad is something great and makes their life different because of the lottery. Only three students left this ad unanswered though they are given enough time to do that. None of the students mention anything about meaning whether conceptual or else. Not sparingly, only two students do claim that the ad designer should mention money in the ad so as to attract people's attention. According to the students' comprehension of the first ad, 'It could be you!' it is obvious that both male and female students almost have the same idea about it.

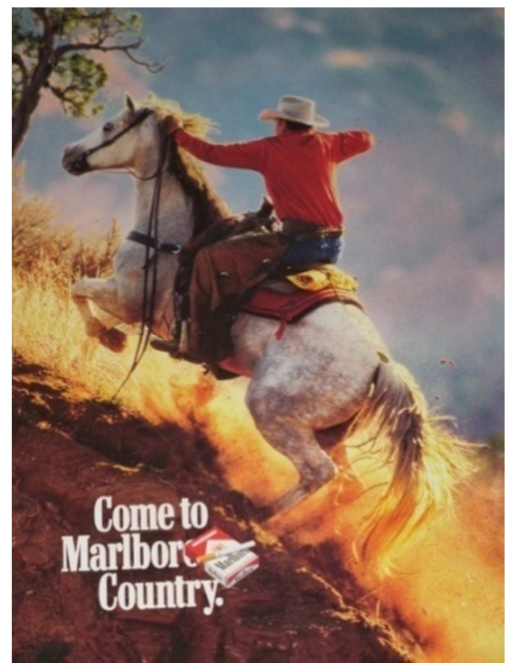

Ad. 2. Come to Marlboro country.

According to the stereotyped thought of people smoking is very unhealthy. Despite bad effects on man's health, cigarette companies advertise to get people buying their products. There are thousands of cigarette companies and they do advertise for selling different products they have.

The hidden message of this ad is that smoking is fun. At the word level, it can be said that 'come' is an intransitive verb expressing movement, 'Marlboro' is a proper noun, and 'country' is a homeland or a state where somebody was born or is a citizen. This socio-cultural experience is embodied in the word order of this ad. Moreover, the importance form of this sequence of linguistic items makes it as a kind of invitation letter which invites all the people to visit Marlboro country. So, the ad designer's attitude towards the audience (or ad itself) shapes the ways of his/her language use (see Palmer, 1981: 35-6). As regarded, the relationship between this concept and that can be associated with this ad, one can claim that this concept can be interpreted as 'amusement', 'relaxing', 'having fun', 'bravery', 'manhood', etc. So, the message of this ad is to say that in 'Marlboro Country' all dreams become true since it is a fairy land and people should not miss the fun of smoking.

Unlike the students' understanding of the first ad, for the second one which advertises for Marlboro cigarette, the comprehension of female students is totally different form the male ones. To be more accurate, all female students $(50 \%$ of the study sample) do believe that smoking is bad and they do not like such types of advertisement. So, most of them write that ad no. 2 is not good since it affects human health; that's why none of them write their own understating. The reason behind having such a strange feminine answer is that 
in eastern societies most of the females do not smoke; they hate (or probably not allowed) to smoke. This has a strong relationship with the students' life. This is true with only four male students (i.e., 20\%) who believe that smoking is dangerous and this type of ad should not be published. So, the connotative meaning of more than half of the students is to have a negative feeling about smoking. A few students $(15 \%)$ state that the ad is about cigarette; this may be interpreted as being careless about smoking. In other words, smoking means nothing to them. Only three students think that the ad is attractive and Marlboro means challenge, fame, bravery, etc. To sum up, one can conclude that the students' life experience and background knowledge affect their comprehension of the ad.

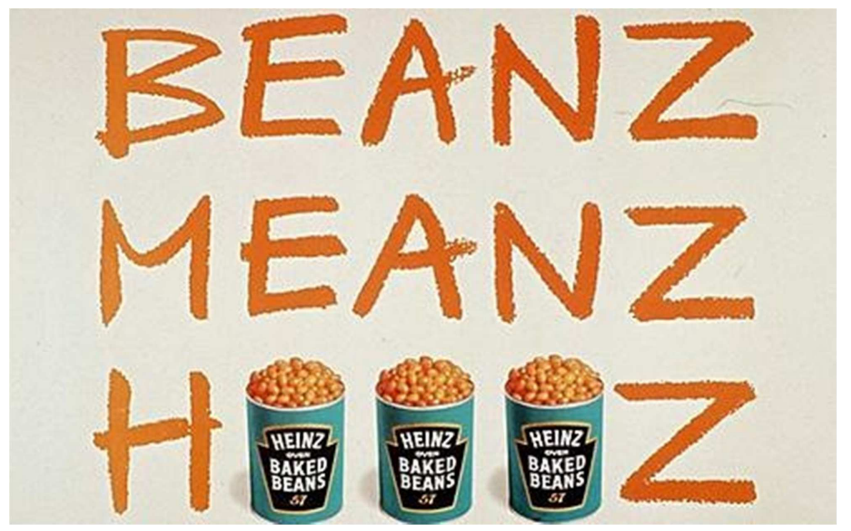

Ad. 3. Beanz Meanz Heinz.

Unlike the ads mentioned above, 'Beanz Means Heinz' has a rhythm and rhyme. This makes it to be uttered very fast and for sure it attracts people's attention. The intended message of this ad is conveyed via organizing the speech in an attractive musical way. The sound harmony among the three words as well as their order makes the ad easily memorized, and consequently changes the customer's perspective about baked beans of Heinz. Furthermore, one can conceptualize the ad as that 'Heinz' is a name while bean(s) (in the ad, Beanz) is a vegetable and to make it easy to be pronounced with 'Heinz', the name of the producer, / $z /$ is put to the end of the word 'bean' (i.e., to have the same rhythm).

The general idea in this ad is to tell the people that when they try to have a real and delicious baked 'bean', they can taste 'Heinz'. However, the assumption is eating 'Heinz' makes people speak fluently and fast and in a rhythmical way 'Beanz Meanz Heinz'.

For non-native speakers and especially for the students, this ad cannot be easily comprehended for they are not familiar with. This is why $40 \%$ of them did not understand it and claimed that the ad sounds ambiguous. $15 \%$ of the study sample suggested redesigning the ad by using one simple sentence; this could be recommended to the copywriters and/or ad designers to think of designing a special ad for non-native speakers in order to better attract their attention. The rest of the sample stated that the ad could be understood smoothly since it is about food.

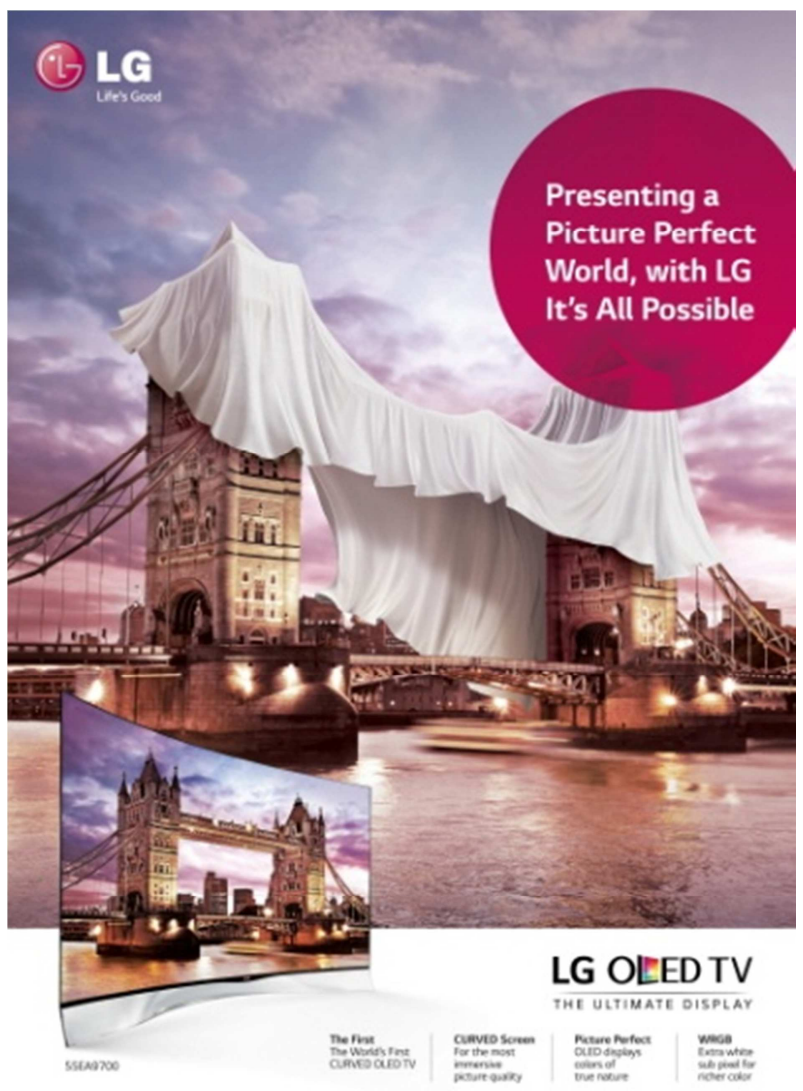

Ad. 4. Presenting a Picture Perfect World, with LG It's All Possible.

Technological devices make people life easier and attract their attention. LG as a company has its own strategies to show its devices up in an attractive way. The text of this ad is to advertise for OLED TV which is very popular nowadays. The designer of this as is enough clever to select a language of high attraction in phrases of 'picture perfect world' and 'all possible'.

In this ad, the company wants to say that what is presented by LG is perfect; the reason could be attributed to the fact that LG presents a device with best quality and what man thinks off is possible with LG. Regarding the audience comprehension, one can state that this ad gives enough information about the product to the people. Concerning types of meaning that one may find in this ad, it is claimed that at the level of conceptual and thematic meaning the ad is well designed. In other words, the linguistic items used are well prepared and performed. 'Presenting a picture' is used to tell the people that the picture by LG is perfect and unlike others. Looking at the phrase 'perfect world', tells the audience the fact that these linguistic items can be considered as a collocative meaning, simply because one can see "the habitual co-occurrence of individual lexical items" * So, what people see on the LG screen is perfect. Beyond this, the ad designer organizes his/her message in a good way which focuses on the fact that everything is possible and predictable with the LG products (i.e., thematic meaning).

The 'all possible' expression has a number of 
connotations; for example 'having a perfect design, highest quality, easy to use, slim, perfect screen, real colours, full HD technology, high volume sound, best picture, etc.' This expression is also associated with all good features of a device. Reflected meaning might be found in this expression since 'all possible' creates part of the people's response to another sense of this expression. Additionally, this expression has also emotional associations that differ from one person to another. Therefore, differences in one's emotion towards one product and another are to a large extent positive (see Palmer, 1981: 63-4; Stubbs, 2002: 34; Riemer, 2010: 388-9). Moreover, at the social level (social meaning), the degree of formality is semi-formal or consultative, in that it correspond to the social situation of the language used by the ad designer (see Joos, cited in Crystal and Davy, 1969: 74; Finch, 2000: 152-3). Therefore, the intended message of this ad is to tell people that LG makes everything possible. However, building on the fact that people experience about each ad (or product) changes their interpretation, almost all the students have the same understanding about this product. They believe that the ad is perfect and LG represents the best quality. For them, LG devices can be used easily and give an opportunity to see the world as it is. Eventually, the students' familiarity of LG devices positively affects their comprehension.

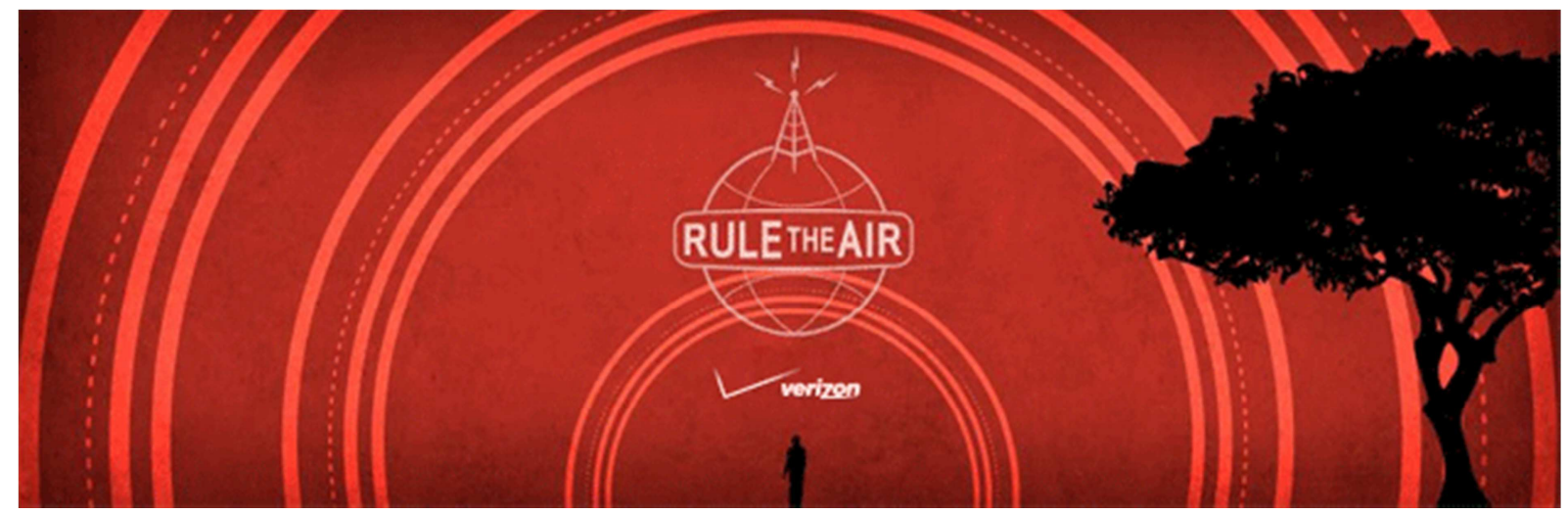

Ad. 5. Rule the Air.

Like many other telecommunication companies, Verizon as one of the American famous company in the field of communication has designed a number of ads in order to attract people's attention. Most commonly, ruling the air for/by the people is illogical thing. The designer of this ad cleverly selected the lexical items to build the strong walls of the required house which is an adorable and delightful advertisement.

With regard to the expected analysis of this ad, one can analyze it at the level of word. In other words, the basic components of meaning (dictionary meaning) is available; 'rule' means having the official power to control things, people, place, etc.; and 'air' refers to a number of gases around the Earth. So, Verizon communicates people via understanding what is performed to them (the ad) in a perfect way since Verizon refers to the cognitive meaning of the linguistic items (see Yule, 2006: 100; Leech, 1981: 9). Yet, the way that the lexical items are organized is impressive since it emphasizes the fact of ruling the universe (i.e., thematic meaning).

In addition to the fact that referential meaning is not the most important components of all linguistic communication acts, mentioning the other side of the ad is prerequisite. Similarly, in this ad there is a meaning which is attached to the linguistic items, i.e., psychologically speaking a number of possible connected lexical items might come to the people's mind (see Finch, 2000: 151). Building on this claim, one can state that 'rule the air' is considered as the consequences of the polysemic nature of the lexical items used in this ad (i.e., reflected meaning) and this leads one to say that these lexical items are capable to convey more than one sense. Furthermore, it is claimed that the expression of 'rule the air' has its communicative value since the socially required meaning can be seen (i.e., connotative meaning); the expression refers to something which goes beyond its "purely conceptual content" (see Leech, 1981: 12). Additionally, the ad designer shows his/her attitudes and viewpoints towards their product and the people who become subscribers (i.e., affective meaning); this means that the language used in this ad has the attitudinal elements in its meaning.

When all is said and done about the expected analysis of this ad, the fact that should be mentioned is that the text of this ad tells people that via using Verizon wireless they can govern the universe and control everything online. In other words, Verizon is the best way to govern the space above the ground; and this invites people to be subscribers.

Concerning the students' answer, 30\% of them left this item unanswered. Lack of the required knowledge to understand this ad makes six students which equals $30 \%$ believe that the ad should be redesigned in another way without mentioning any suggestions. So, this informality changes their perspective about the hidden message of the 'Rule the air'. The rest of the students $(40 \%)$ does mention some points which all indicate students' reliance on connotative meaning: 'with Verizon you can control the world', 'fast in transferring', 'Via using this amazing network, you can rule your communication', 'everyone can use it', 'we can't live without Verizon', etc. 


\subsection{Analyzing Selected Kurdish Ads}

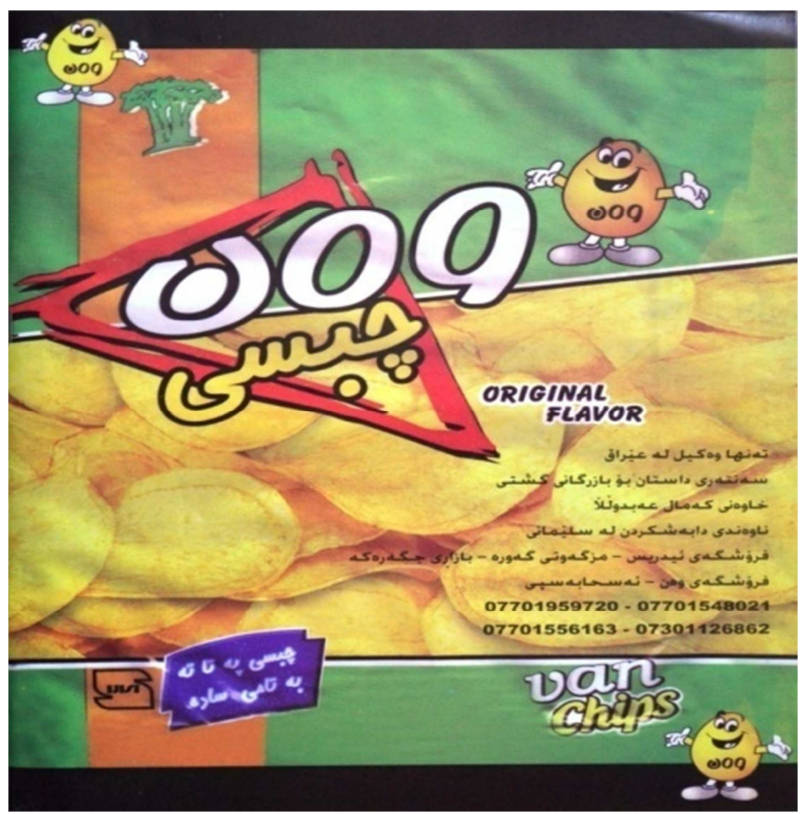

(Chipsi Wan: chipsi patata ba tami sada) (Lit. Van Chips: original flavour)

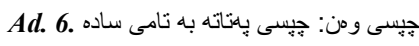

Since food represent one of the most required need of human beings, it has been advertised in numerous good ways. In Iraqi Kurdistan Region, local food product companies have started using their own slogans. The company which produces Van Chips intentionally focuses on the 'original flavour' although other flavours are available. The cognitive meaning available in this ad refers to the literal meaning of words: جيس (chips, 'piece of thin crisp snack food'), ونن (Van, 'a proper name') and 'تامى ساده (tami sada, 'original flavour'). The whole expression is designed in a way to affect customers; this is why רيسى ومن has been thematized. Moreover, this ad is somehow a rhythmical one. Finally, نامى ساده may connotate with ideas such as 'no extra chemical elements', 'pure', 'delicious', 'fresh', etc. and تام 'tam, 'flavour') itself might have a collocative meaning because in Kurdish, it can be found with a number of linguistic items like تامى خوّش (tami xosh, 'delicious taste'), بهنام (batam, 'delicious'),

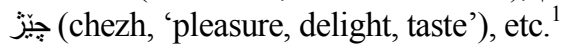

Not surprisingly, the researcher can find a lot of similarities among the students' answer about the Kurdish ads in general. All the students are Kurdish native speakers and almost they have the same social and educational background. In Kurdish culture, it is common that children like potato chips and this affects the students' comprehension. Based on the statistical analysis of the students' performance, eight students (40\%) think that this ad is specialized to attract the child's attention. This means that the students have a sort of experience with this ad in their real life. In other words, the students' associative meaning (e.g. connotative and social meaning) can be found in their answer since they write their understanding building on their experience. Moreover, they think that 'Van' is natural and delicious. On the other hand, $25 \%$ of the students claim that the

1. (see Löbner, 2002: 35; Cowie, 2009: 64 for more information). language of this ad is not attractive and should be redesigned; they think that expressions such as 'Van is no. 1', 'Van is always with you!', 'Your delicious friend is Van' are more attractive. This gives an opportunity to state that the ad designers should give a sample of their ad to a number of people in order to know the people's reflection and understating about different types of ads. Again, the students' experience has a great role in comprehending the message behind this ad; the ad is associated with a number of ideas. To prove this, seven students think that this ad includes 'delicious', 'best food', 'cheaper', 'good quality', 'unhealthy', etc.

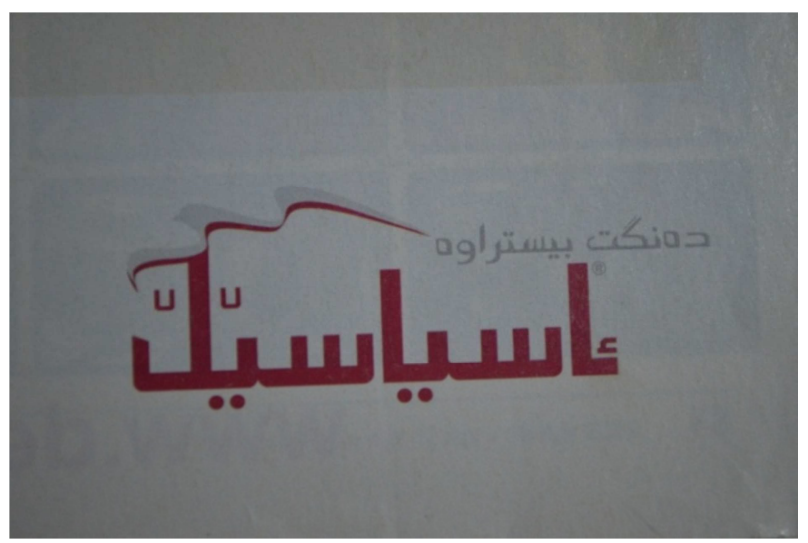

(Asiya seL: dangit bistrawa!) (Lit. Asia Cell: your voice is heard!)

$$
\text { Ad.7. اسيا سيّلّ: دمنكت بيستر اوه }
$$

This is one of the most essential ads of Asia Cell which is a big telecommunication system company in Iraqi Kurdistan Region and Iraq. Like other companies, this ad is well designed to comply with the Kurdish culture and society. At the conceptual, one may refer to dictionary and state that بيستراوه (dangit, 'your voice') stands for speech; and (bistrawa, 'is heard', i.e., when one listens to something or gets to know something). These linguistic items are well selected to reflect the intended message.

Associative meaning which in turn mirrors the intended message of the ad: tell the people (especially subscribers) that using Asia Cell means having the best quality of mobile communications service. So, دهنكت بيستر اوه has a number of connotative meanings: 'no problem with communication', 'easy to make communication', 'best quality', 'never busy', 'best connection', 'best offers', 'your desires are fulfilled', etc. (see Kreidler, 1998: 44-5). Moreover, it touches the Kurdish people mood and suits their collective nature (unlike the individualistic American nature). This ad, then, may well keep them all in touch and work together. The ad is also effective since the language used is very simple and understandable.

The students' performance is a good evidence to support the idea that associative meaning is wider and more complex comparing with the referential meaning. 'Asia Cell' for 12 students has a number of psychological connections which are related to their experience with this company. In other words, $60 \%$ of the study sample claims that 'ئاسيا سيّل: دهنحت بيستر اوه' is very attractive; because of 
the use of this network, the students are more capable to write their reflection towards this product. More than half of the sample considers this ad as one of the most attractive one building on the psychological and sociological aspects of their life. In addition, 12 students accept that the ad connotes a number of other possible meanings such as 'keep relationships on', 'very successful', 'communicate with others easily', 'Asia Cell makes our life easier', 'make people contact each other', 'we need it, we use it', etc. So, most of the students have a positive connotative and affective meaning of the ad. On the other hand, seven students which constitute $35 \%$ of the study sample suppose that there is no relation between the ad and what is presented in reality. This means that the feelings they have are negative; this is postulated according to what they have experienced in reality. The reason behind this unpleasant feeling and disagreeable reflection, as they claim, is related to the fact that costs too much and this high price changes their perspective about the ad and the company as well. Besides, only one student suggests that this ad should be redesigned and she does not declare her suggested one.

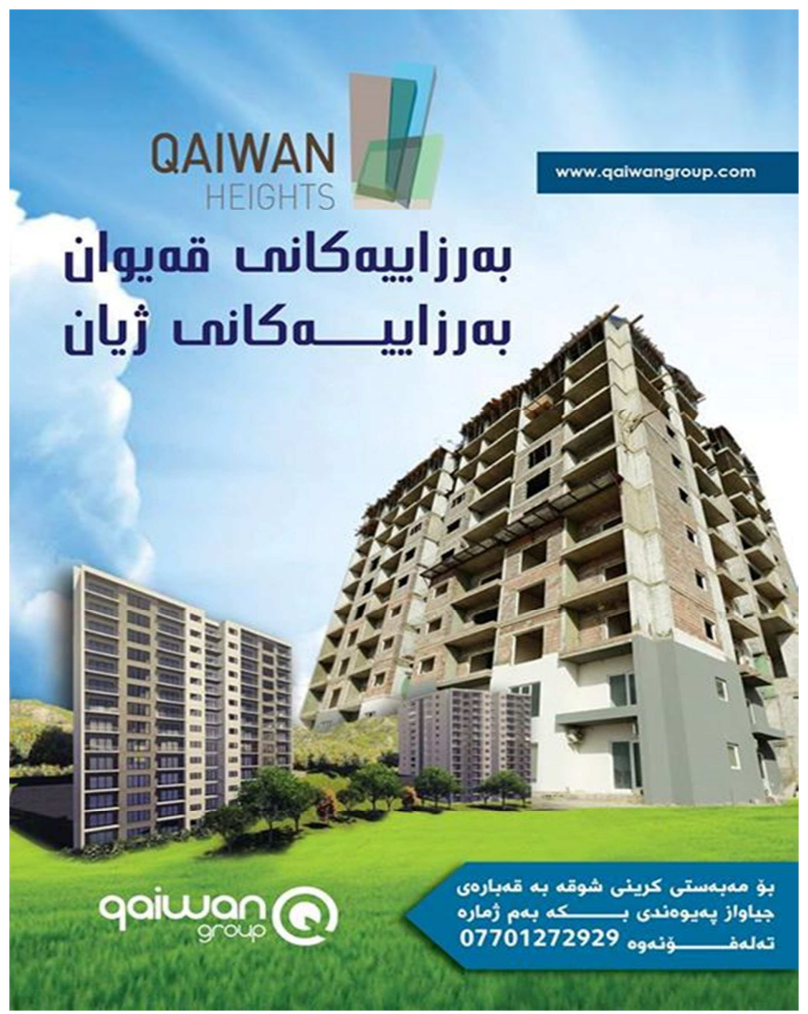

(Barzayiakani Qaywan: barzayiakani zhiyan) (Lit.: Qaywan Heights: the Heights of Life)

$$
\text { Ad. 8. بمرز اييهكانى قميو ان: بارز اييهكانى زئان }
$$

Recently, many companies and organizations in Iraqi Kurdistan Region attempt to build residential buildings and apartments; so they do advertise their products and services. This can be used as evidence to Williamson's (1983: 11) claims "advertisements are one of the most important cultural moulding and reflecting our life today."
In this ad, the cognitive meaning is carried out by the linguistic items: بهرزاييهكان (barzayiakan, 'heights'), قهيوان (Qaywan, 'name of a mountain in Sulaymaniyah city; proper noun'), زيان (Zhiyan 'life'). قهيوان is associated with a number of good concepts in the mind of Kurdish people; this is why the company cleverly selects this name to be in the ad. For any Kurdish who sees this mountain, the concept of بهرز اييككانى قهيوان (barzayiakani Qaywan, 'Qaywan Heights') could be connected with 'high place', 'fresh air', 'nature', 'romantic view', 'high palace', 'new life', 'wealthy', 'healthy', 'high life', 'high social status', 'being rich', etc.; these can be mentioned as the connotative meaning of Historically speaking, Kurds as a nation are associated with life in mountains; so building on this, the ad designer carefully selects the expressions which highlight this thematic meaning. Moreover, بكرزاييهكانى زيان has "the attitudinal element in meaning"; it clearly shows the personal attitudes, thoughts, feelings, and viewpoints of the ad designer (or the company owner) towards the product, on the one hand, and the audience on the other hand (see Leech, 1981: 15; Crystal, 2008: 15). Furthermore, the expression of بهرز could support Leech's (1981: 14) claim in which language users "decode the social meaning of a text through our recognition of different dimensions and levels of style.” Additionally, بهرز اييهكانى زيان might be used as a sign for social high status. Yet, one can claim that the word order of this ad has a great role in illustrating emphasis, i.e., thematic meaning.

Kurdish EFL students live in one society and this affects their reflection towards the ads especially the Kurdish ones. Most commonly, the study sample thinks that the language of بارز اييهكانى قهيو ان: بارز اييهكانى زيان invites people to try the product. Based on the analyzed data, one can maintain that 13 students (which make $65 \%$ of the sample) claim that this ad encourages people to buy an apartment so as to have a better life. They agree upon the point that this ad brings them some good feelings as: good location, high quality, international standard, spotless environment, amazing life, perfect service, best place to live, good choice, etc. On the contrary, $30 \%$ of the students (i.e., six students) have a negative perspective about the real value of the product. The reason behind that could be attributed to the students' life style. More generally in the society, some people think that advertising is something while the product is something else. So, a number of the students believe that these types of buildings (or what is known as modern cities and/or villages) are not for all people. That is, only a certain class of people can afford for it. Predictably then, following this agreement, the students with lower income would have a negative reflection towards this ad and vice versa. This supports the idea that people life style gives different understating of any linguistic items used in a sentence for a certain purpose. Unlike English ads, when the students recommend redesigning a Kurdish ad they give options; for this ad 5\% of the sample suggests 'Qaiwan Heights: perfect life!' 


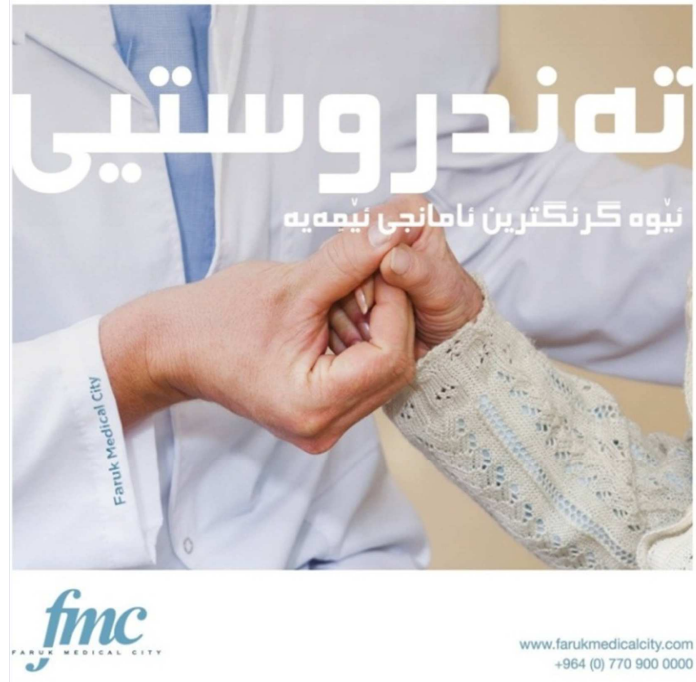

(Tandrustiy 'ewa grngtrin 'aamanji 'emaya) (Lit.: We put your health at the forefront of our priorities)

$$
\text { Ad. 9. تهندروستيى ئيّوه كَرنكترين نامانجى ئيّمانيه }
$$

Generally speaking, private (non-governmental) sectors try to find many different ways to advertise their products, service, and achievement. Historically, "health" is one of the fields that companies try to invest so as to get benefit. FMC (Faruk Medical City) as a modern health center does claim that people's health is the most important task. So, the intended message is attracting people's attention via claiming that people's health is FMC's priority.

In this ad, the central factor of the communication between the company and the people refers to the essential components of the lexical items. To be more specific, the dictionary meaning is conveyed by a number of linguistic items, for example: تهندروستى (tandrusti, 'health') refers to the

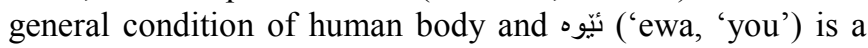
personal pronoun which refers to a group of people when speaking and/or writing to them. In Kurdish language, unlike English, ئيّو (ewa) for plural and (to) for singular stand for 'you', so the language of the ad is directed to the people as a whole not to individuals. Furthermore, the use of superlative adjective of كرنكترين (grngtrin, 'the most important') is highly selected and attractive as well; and 'ئامانج ('aamanj, 'aim, purpose, goal, object, target, priority, etc.') refers to something that people give priority over anything else. Again, another personal pronoun ئيّمه ('ema, 'we') is used in the ad; ئيّها in Kurdish language refers to a group of people

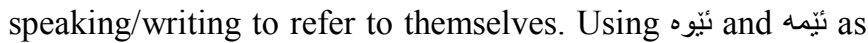
two plural pronouns indicates that the collectivist nature of Kurdish society is prominent in the ad, so ads reflect the culture of the language used in them and the nature of the society as well.

No doubt, building on the personal life experience the people decoding differs from one person to another. That is, the psychologically connected items which come to someone's mind (i.e., the sense of association) are not the same to all people. So, the whole expression is used to attract people's attention especially the patients. Regarding the stylistic meaning in this ad, it is clear that the language of the ad is very consultative and more standard (see Löbner, 2002: 27). Moreover, the lexical items show the positive feeling of the ad designer and/or the company towards FMC and the people's health (i.e., affective meaning). Furthermore,

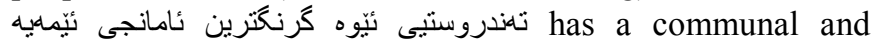
personal emotional association; that is, the ad's secondary meaning which goes beyond its essential one has a communicative value.

Although all the English and Kurdish ads are designed and published mainly for the commercial purposes, $20 \%$ of the students claim that this ad is not like what is presented in reality; they declare that having the high price affects their interest in trying this product. So, some students do write their understating from the quantity of payment; in this case the answer of the students who have a good life will be different from those whose life is not that good. Generally speaking, most of the students support the language used in this ad; they agree that it is very attractive. Statistically speaking, four students (i.e., 20\%) associated تهندروسنيى ئيّوه كرنكترين ئامانجى ئيّمهيه used to show negative feelings. Furthermore, a few students claim that using other lexical items in this ad is necessary to attract people's attention. In this regard, only $10 \%$ of the students suggest that this ad should be redesigned.

In sum, being familiar with the culture of the language in which the ad is designed is necessary since it helps the consumers comprehend the hidden message of the ad. The data of the current study verify this hypothesis; almost all the students understand this ad well while they face problem in comprehending the English ones. They are familiar with English, but face problems with some aspects of English culture. In this ad, 14 students (70\%) understand the hidden message behind this ad in different ways. This group of students supports the language which is used in designing the ad; they attach the lexical items with a number of psychologically connected items such as 'best healthcare', 'best medicine', 'people are well protected', etc.

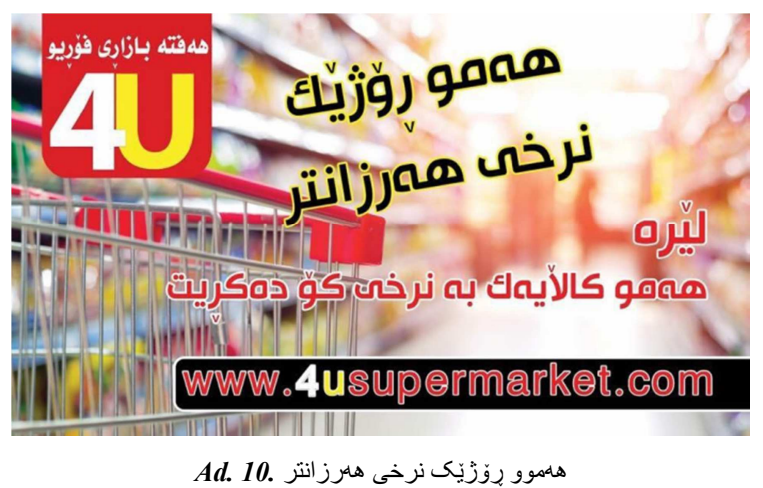

(Hamw Rozhek nrkhi harzantr) (Lit.: Every day the price is cheaper.) لِّره هلمورو كالايبك به نرخى كوّ دمكريت

(lera hamw kaLayak ba nrkhi ko dakRit) (Lit.: Here you can buy everything with the wholesale price)

Generally, people usually go shopping as a daily activity; they look after the cheaper (or even the cheapest) price. In 
fact, most of the companies try their best to advertise that they are the best because of the price they have. In this regard, ad designers present their production to the people

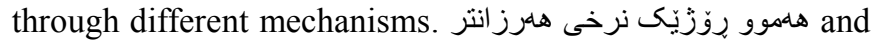
ليّره هلموو كالآيهك به نرخى كوّ دمكريت are two of the ads used by $4 \mathrm{U}$ supermarket in order to attract people's attention. As regards the dictionary meaning, it is a prerequisite to analyze each lexical item: هلمور روَّزيّك (Hamw Rozhek, 'every day, each day'), نرخ (nrkh, 'price: an amount of money that people pay for something'), هلرزانتر (harzantr, 'cheaper - a comparative adjective which meaning costing very little money', 'reasonable', 'affordable', 'extremely cheap', 'low price', etc.). Furthermore, the second part of the ad encapsulate conceptual meaning: لَّرّه (lera, 'here', 'in this place', etc.), هلموو كالّايهك (hamw kaLayak, 'everything', 'all things', 'the whole of thing', etc.), نرخى كو '(nrkhi ko, 'wholesale price', 'large quantity at low price', etc.), and دمكريت (dakRit, 'a transitive verb which means buying something'). At the level of word, one can claim that the essential components are highly selected to attract Kurdish consumers' attention.

To analyze the expected associative meaning in the ad, it may be useful to start with the most common type of it which

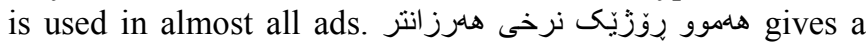
very positive impression about the supermarket which makes people visit the place every day and the low price makes this happen. نرخى هلرزانتر is an attractive expression and it

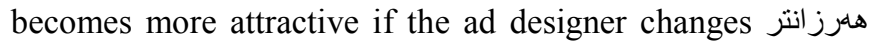
(cheaper) to هلرزانترين (cheapest). Through using هلرزانتر, the ad designer wants to display his/her personal ideas and feelings towards the supermarket in order to associate their products with the people's emotion (i.e., affective meaning). لليّره هلموو كالآيهك به نرخى كو دهكريت is attractive due to the use of نرخى كو دك دئ (wholesale price) since it is a positive feeling of the supermarket. Moreover, the social meaning is available since the social situation of language is conveyed in the ad. In terms of formality, the language is consultative so as to collect more people in the place. نرخى كو is the most important part of the ad due to the fact that it attracts consumer's attention. The hidden message of the ad is that people go shopping and the best place to do so is this place since everything is sold with the wholesale price and this is an everyday offer. Finally, the grammatical construction of the ad is very important; it focuses on the fact that whenever people buy things there they never regret it.

The results of the test show that the participants' response to this item is not the same; the majority of students (18 which mean 90\%) answer this item almost in a similar way. This indicates the fact that the students believe that the expressions used in this ad can be found in real life. So, when the students find the ad in reality, they show up their positive reaction towards the supermarket itself. Among these 19 students, most of them have visited the supermarket and found that what is demonstrated in the ad is correct. Moreover, the data indicates that students seek for finding cheap price while shopping; they connect this ad with a number of ideas such as: '4U... the place we should visit!', 'cheaper price', 'best place for shopping', 'the cheapest market to buy goods', etc. Because of the students' carelessness $5 \%$ (only one student) left the item unanswered; and another student believed that this ad should be redesigned.

\section{Results and Conclusions}

Table (2) shows seven types of meaning in selected English and Kurdish commercial ads, the range of which is different from one ad to another in both cultures.

Table 2. Summary of the Types of Meaning in the Study Sample.

\begin{tabular}{|c|c|c|c|c|c|c|c|c|c|c|c|}
\hline \multirow{2}{*}{ Types of Meaning } & & \multicolumn{5}{|c|}{ English Ads } & \multicolumn{5}{|c|}{ Kurdish Ads } \\
\hline & & Ad. 1 & Ad. 2 & Ad. 3 & Ad. 4 & Ad. 5 & Ad. 1 & Ad. 2 & Ad. 3 & Ad. 4 & Ad. 5 \\
\hline Conceptual Meaning & & $\sqrt{ }$ & $\sqrt{ }$ & $\sqrt{ }$ & $\sqrt{ }$ & $\sqrt{ }$ & $\sqrt{ }$ & $\sqrt{ }$ & $\sqrt{ }$ & $\sqrt{ }$ & $\sqrt{ }$ \\
\hline \multirow[t]{6}{*}{ Associative Meaning } & Connotative Meaning & $\sqrt{ }$ & $\sqrt{ }$ & $\sqrt{ }$ & $\sqrt{ }$ & $\sqrt{ }$ & $\sqrt{ }$ & $\sqrt{ }$ & $\sqrt{ }$ & $\sqrt{ }$ & $\sqrt{ }$ \\
\hline & Social Meaning & $\sqrt{ }$ & & & $\sqrt{ }$ & & & $\sqrt{ }$ & $\sqrt{ }$ & $\sqrt{ }$ & $\sqrt{ }$ \\
\hline & Affective Meaning & $\sqrt{ }$ & & & & $\sqrt{ }$ & $\sqrt{ }$ & & & $\sqrt{ }$ & $\sqrt{ }$ \\
\hline & Reflected Meaning & $\sqrt{ }$ & & & & $\sqrt{ }$ & & $\sqrt{ }$ & & & \\
\hline & Collocative Meaning & & & & & & $\sqrt{ }$ & $\sqrt{ }$ & & & \\
\hline & Thematic Meaning & $\sqrt{ }$ & $\sqrt{ }$ & $\sqrt{ }$ & $\sqrt{ }$ & $\sqrt{ }$ & $\sqrt{ }$ & $\sqrt{ }$ & $\sqrt{ }$ & $\sqrt{ }$ & $\sqrt{ }$ \\
\hline
\end{tabular}

English and Kurdish ads have their own psychological, philosophical and linguistic effects on people. These effects enhance the idea of having different types of meaning. The language which is used in any ad, for instance, should be highly selected and easy to be grasped by ordinary people. Moreover, culture has a great role in designing ads.

The study has come up with some conclusions:

1. The results of the study show that conceptual meaning is basic for shaping the idea behind the ad; it is less important than what can be associated with it; while associative meaning is more effective.

2. Connotative meaning is the most common type of associative meaning in all English and Kurdish ads. So, the ad designers are very smart in addressing the people's emotional side through associations that some lexical items might provoke.

3. Since everything starts with the first step of designing an ad, the thematic meaning becomes influential in designing ads, i.e., word order, grammatical construction, emphasis and ordering, stress and intonation, etc.

4. Most of Kurdish EFL university students do not have enough knowledge about the target culture and the structure of English society. This makes them unable to 
comprehend the intended message of the ads. So, they need to be familiar with some basic aspects of English culture. Furthermore, their familiarity with any advertised products positively influences their comprehension and makes them think of different types of associative meaning in the ads.

5. Building on their social background, most of the students do list the ads in terms of goodness and badness. For example most of them believe that 'Welcome to Marlboro country' is something bad since it advertises smoking. Moreover, the students' comprehension is to large extent determined by some psychological factors that are closely related to their daily life.

\section{Acknowledgements}

I would like to express my sincerest gratitude to Prof. Dr. Anis Behnam Naoum for his continuous support and proofreading the whole work.

\section{References}

[1] Aitchison, J. (2008). The Articulate Mammal: An introduction to Psycholinguistics. $5^{\text {th }}$ Edition. Oxen: Routledge.

[2] Akmajian, A.; Demers, R.; Farmer, A.; and Harnish, R. (1995). Linguistics: An Introduction to Language and Communication. $4^{\text {th }}$ Edition. US: MIT Press.

[3] Bowdery, R. (2008). Basics Advertising: Copywriting. Switzerland: AVA Publishing SA.

[4] Bussmann, H. (1996). Routledge Dictionary of Language and Linguistics. (G. Trauth and K. Kazzazi, Trans). London: Routledge.

[5] Cowie, A. (2009). Semantics. Oxford: Oxford University Press.

[6] Crystal, D. (1992). An Encyclopedic Dictionary of Language and Languages \& Phonetics. London: Blackwell Publishing LTD.

[7] --- --. (2008). A Dictionary of Linguistics \& Phonetics. $6^{\text {th }}$ Edition. London: Blackwell Publishing.

[8] Crystal, D. and Davy, D. (1969). Investigating English Style. England: Longman Group Ltd.

[9] Finch, G. (2000). Linguistic Terms and Concepts. London: Macmillan Press LTD.

[10] Garman, M. (1990). Psycholinguistics. Cambridge: Cambridge University Press.

[11] Goldstein E. B. (2007). Cognitive Psychology: Connecting Minds, Research, and Everyday Experience. $2^{\text {nd }}$ Edition. Massachusetts: Wadsworth.
[12] Hurford, J.; Heasley, B.; and Smith, M. (2007). Semantics: A Course Book. $2^{\text {nd }}$ Edition. Cambridge: Cambridge University Press.

[13] Kearns, K. (2011). Semantics. $2^{\text {nd }}$ Edition. London: Palgrave Macmillan.

[14] Kreidler, Ch. (1998). Introducing English Semantics. London: Routledge.

[15] Kuiper, K. and Allan, W. (1996). An Introduction to English Language: Sound, Word and Sentence. London: Macmillan Press LTD.

[16] Leech, G. (1981). Semantics. $2^{\text {nd }}$ Edition. Great Britain: Richard Clay (The Chaucer Press) LTD.

[17] Löbner, S. (2002). Understanding Semantics. London: Arnold Publisher.

[18] Lyons, J. (1977). Semantics. Volume 1. Cambridge: Cambridge University Press.

[19] --- --- ---. (1981). Language and Linguistics: an Introduction. Cambridge: Cambridge University Press.

[20] Ogden, C. K. \& Richards, I. A. (1923 [1946]). The Meaning of Meaning: a Study of the Influence of Language upon Thought and of the Science of Symbolism. $8^{\text {th }}$ Edition. New York: Harcourt, Brace \& World, Inc.

[21] O'Grady, W. (2005). "Semantics: The Analysis of Meaning". In W. O'Grady; J. Archibald; M. Aronoff; J. Rees-Miller, (Eds), Contemporary Linguistics: an Introduction. (pp. 201244). $5^{\text {th }}$ Edition. New York: Bedford/St. Martins.

[22] Palmer, F. (1981). Semantics. $2^{\text {nd }}$ Edition. Cambridge: Cambridge University Press.

[23] Saeed, J. (2009). Semantics. $2^{\text {nd }}$ Edition. UK: Blackwell Publishing.

[24] Stubbs, M. (2002). Words and Phrases: Corpus Studies of Lexical Semantics. Oxford: Blackwell.

[25] Tanenhaus, M. K. (2008). Psycholinguistics: An Overview. In F. J. Newmeyer (Ed.), Linguistics: The Cambridge Survey. Volume III. (Language: Psychological and Biological Aspects). (PP. 1-37) Cambridge: Cambridge University Press.

[26] Wehmeier, S. (Editor). (2000). Oxford Advanced Learner's Dictionary, $6^{\text {th }}$ Edition. Oxford: Oxford University Press.

[27] Yule, G. (2006). The Study of Language. $3^{\text {rd }}$ Edition. Cambridge: Cambridge University Press.

[28] Riemer, N. (2010). Introducing Semantics. Cambridge: Cambridge University Press.

[29] Widdowson, H. G. (1996). Linguistics. Oxford: Oxford University Press.

[30] Williamson, J. (1983). Decoding Advertisements: Ideology and Meaning in Advertising. London: Marion Boyars.

* (For more information see Crystal, 2008: 86). 